DOI 10. 18307/2022. 0108

(c) 2022 by Journal of Lake Sciences

\title{
环太湖各水资源分区入出湖河流总磷浓度与负荷变化分析”
}

\author{
李琼芳 ${ }^{1,2}$, 许树洪 ${ }^{1}$, 陈启慧 ${ }^{* * *}$, 贾小网 ${ }^{3}$, 严方家 $^{1}$, 朱玉婷 ${ }^{1}$, 林 鹏 $^{1}$, 摹 云 $^{1}$ \\ (1: 河海大学水文水资源学院,南京 210098) \\ (2:长江保护与绿色发展研究院,南京 210098) \\ (3: 江苏省水文水资源勘测局泰州分局,泰州 225300)
}

\begin{abstract}
摘 要: 人出湖总磷负荷变化是影响太湖湖体磷收支平衡的关键因素. 基于 2012-2018 年水质水量监测资料, 计算全湖 及各水资源分区河流入出湖总磷负荷, 并以水量加权计算其总磷年平均浓度, 探明其时空变化规律; 运用双累积曲线法 分析不同分区水污关系的变化规律; 以月为时间尺度,利用 Pearson 相关系数,揭示人湖总磷负荷分别与人湖水量、人湖 总磷浓度的相关关系; 通过讨论分析, 明确适用于太湖的人湖总磷平均浓度计算方法、总磷负荷影响因素及控制途径. 研 究结果表明: (1) 水量加权法比算术平均法更加适用于太湖人湖总磷平均浓度的削减管理; 环太湖河流入湖总磷浓度多 年平均值为 $0.189 \mathrm{mg} / \mathrm{L}$, 明显高于出湖的 $0.079 \mathrm{mg} / \mathrm{L}$, 入湖总磷负荷多年平均值为 $2206.51 \mathrm{t}$, 也高于出湖的 $873.73 \mathrm{t} ; 2016$ 年丰水年人、出湖及净人湖总磷负荷均最高, 分别为 $2993.9 、 1341.1 、 1652.8$ t. (2) 湖西区河流人湖总磷浓度多年平均高于 所有其他分区, 其值为 $0.226 \mathrm{mg} / \mathrm{L}$, 浙西区、武澄锡虞区河流出湖总磷浓度多年平均分别为 0.114 和 $0.109 \mathrm{mg} / \mathrm{L}$, 均高于 其他分区. 不同水资源分区的水污关系呈现不同的年际变化规律,但除杭嘉湖区外, 其他分区均未表现出人湖总磷得到 有效控制的迹象. (3) 湖西区和浙西区人湖总磷年负荷多年平均值分别为 1748.71 和 $278.61 \mathrm{t}$,两区各年人湖总磷负荷占 总人湖负荷的比重位居前二, 湖西区的都在 $67.88 \%$ 以上; 而浙西区在 7\% 19\% 之间变化; 太浦河出湖总磷年负荷多年平 均值为 $272.27 \mathrm{t}$, 自 2014 年起其占出湖总磷年负荷的比重均在 $30 \%$ 以上. (4) 不同水资源分区月人湖总磷负荷均与人湖 水量存在较好的相关关系, 且除阳澄淀泖区外, 其他分区月尺度人湖总磷负荷变化主要受人湖水量控制. (5) 2016 年丰水 年湖西区人湖河流总磷浓度较高、入湖水量大的共同作用导致了其入湖总磷负荷的显著增加. 研究成果可为太湖的磷外 源负荷控制提供科学依据.
\end{abstract}

关键词: 太湖;水资源分区; 总磷;负荷;时空变化;双累计曲线

\section{Analysis on the variation of total phosphorus concentrations and loads of inflow and out- flow rivers from different water resources zones around Lake Taihu*}

Li Qiongfang ${ }^{1,2}$, Xu Shuhong ${ }^{1}$, Chen Qihui ${ }^{1 * *}$, Jia Xiaowang ${ }^{3}$, Yan Fangjia ${ }^{1}$, Zhu Yuting ${ }^{1}$, Lin Peng ${ }^{1}$ \& Gao Yun ${ }^{1}$

(1: College of Hydrology and Water Resources, Hohai University, Nanjing 210098, P.R.China)

(2: Yangtze Institute for Conservation and Development, Nanjing 210098, P.R. China)

(3: Taizhou Branch, Jiangsu Hydrology and Water Resources Survey Bureau, Taizhou 225300, P.R.China)

Abstract: The variation in inflow and outflow total phosphorus (TP) loads is a key factor affecting the balance of the phosphorus budget for Lake Taihu. Based on the monitoring data of water quality and quantity from 2012 to 2018 , the TP load of the rivers in each water resources zone around Lake Taihu were calculated, the flow-weighted mean annual concentrations of TP were attained, and their spatio-temporal variations were analyzed; the double accumulation curve method was adopted to analyze the relationships between water quantity and TP load in different zones; the Pearson correlation coefficient was utilized to reveal the correlation between the TP load and water quantity as well as TP concentrations of the inflow at the monthly time scale; through discussion and a-

* 2021-02-18 收稿;2021-06-29 收修改稿.

江苏省水利科技项目 (2018001) 和国家自然科学基金项目 (51879069) 联合资助.

** 通信作者;E-mail : chenqh@ hhu.edu.cn. 
nalysis, the calculation method of the average TP concentration of inflow applicable to Lake Taihu, the influencing factors of TP loads and measures of controlling the TP load were investigated. The results showed that: (1) The flow-weighted mean concentration of TP is the preferred approach for calculating average concentrations of tributaries with variable flows for Lake Taihu; The average annual TP concentration of inflow rivers of Lake Taihu was $0.189 \mathrm{mg} / \mathrm{L}$, significantly higher than that of outflow rivers $(0.079 \mathrm{mg} / \mathrm{L})$. The average annual TP load of the inflow was $2206.51 \mathrm{t}$, which was also much higher than that of the outflow $(873.73 \mathrm{t})$; in the high flow year of 2016, the TP loads of the inflow, outflow and net inflow of the lake were the largest among 2012-2018, and their values were 2993.9, 1341.1 and 1652.8 t, respectively. (2) The average annual TP concentration of inflow rivers in the Huxi zone was $0.226 \mathrm{mg} / \mathrm{L}$, which was higher than that in other zones; the average annual TP concentrations of outflow rivers in the Zhexi and Wuchengxiyu zones were 0.114 and $0.109 \mathrm{mg} / \mathrm{L}$, which were higher than those in other zones. The interannual variation of the relationships between water quantity and TP load in different water resources zones behaved differently, suggesting that TP pollution was not effectively controlled on the whole except in the Hangjiahu zone. (3) The average annual TP load of the inflow rivers in the Huxi zone and Zhexi zone were 1748.71 and $278.61 \mathrm{t}$, respectively. The Huxi zone accounted for above $67.88 \%$ of the annual total inflow TP load, and the percentage for the Zhexi zone was between $7 \%$ and $19 \%$; the average annual outflow TP load of Taipu River was $272.27 \mathrm{t}$ and accounted for more than $30 \%$ of the total outflow TP load since 2014. (4) There were good correlations between the monthly TP load and water quantity of the inflow in different water resources zones. Moreover, except in the Yangchengdianmao zone, the variation of monthly TP load of the inflow in other zones was mainly controlled by the water quantity of the inflow. (5) In the high flow year of 2016, the combined effect of high concentration of TP and large water quantity of inflow rivers in the Huxi zone led to a significant increase in the TP load of the inflow. The research results can provide a scientific basis for external phosphorus load control for Lake Taihu.

Keywords: Lake Taihu; water resources zones; total phosphorus; load; spatio-temporal variation; double cumulative curve

太湖流域位于经济发达的长三角地区,以太湖为中心,分为上、下游水系两个部分,上游主要为西部山 区独立水系,有苕溪、南河、洮滆水系等,下游主要为平原河网水系,主要有东部黄浦江水系、北部沿江水系 和南部沿杭州湾水系. 按照流域水系、地质单元及行政区划界限,并考虑与防洪水利分区相一致的原则,太 湖流域分为 8 个 4 级水资源分区,分别为浙西区、湖西区、太湖区、武澄锡虞区、阳澄淀泖区、杭嘉湖区、浦东 区和浦西区. 南河、洮滆水系位于湖西区,是太湖上游来水的主要源地;苕溪水系位于浙西区,分为东西两 支,在湖州汇合人湖;黄浦江水系以黄浦江为主干, 是流域最具代表性的平原河网,黄浦江是流域最重要的 排水通道; 沿江水系位于太湖北部, 主要河道包括新孟河、新沟河、望虞河等重要的沿江引排通道; 位于杭嘉 湖平原南部的人杭州湾河道, 是流域南排的重要通道.

随着太湖流域高度密集化的农业生产和高速城市化的发展, 太湖富营养化问题始终没有得到根本的解 决 ${ }^{[1-2]}$. 磷作为湖泊富营养化的重要控制因子, 控制湖体磷浓度一直是治理太湖富营养化的重点 ${ }^{[3-4]}$.太湖水 体磷浓度主要受出入湖磷收支平衡 ${ }^{[5-6]}$ 、湖体水体一沉积物交换平衡 ${ }^{[7-8]}$ 、水相生物吸收与分解释放平衡 ${ }^{[9-10]}$ 等影响,但在现阶段,控制削减外源人湖磷仍是治理太湖富营养化的关键任务之一 ${ }^{[11]}$. 因此, 很有必要深人 分析出人太湖河流总磷浓度与负荷的时空变化及分布特征. 已有学者开展了相关研究: 谢艾玲等 ${ }^{[12]}$ 、吕文 等 ${ }^{[13]}$ 和 $\mathrm{Xu}$ 等 ${ }^{[14]}$ 探明了人湖总磷负荷的空间变化特征, 均认为西北部河流人湖水量较大, 导致相应的人湖 磷负荷也较大, 而贡湖、东部沿岸区则以出湖负荷为主. 易娟等 ${ }^{[15]}$ 和马倩等 ${ }^{[16]}$ 揭示了入湖河道的总磷浓度 变化特征,前者发现 2007-2014 年期间江苏、浙江两省 22 条人湖河道总磷浓度均呈现下降趋势, 而且得出 了江苏省河道总磷浓度大于浙江省的结论; 后者研究表明湖西区人湖河道总磷浓度与望虞河的总磷浓度之 比在 $1.10 \sim 3.20$ 之间, 望虞河人湖总磷浓度明显小于湖西区各河流的. 翟淑华等 ${ }^{[17]}$ 、朱伟等 ${ }^{[18]}$ 剖析了人湖 负荷变化的影响因素, 指出流域大洪水造成河道输人太湖的总磷负荷骤增. 然而, 值得一提的是, 已有的相 关研究要么以行政区划、要么仅以部分地理单元 (如太湖西部沿岸) 为研究对象分析人出湖总磷变化, 但以 具有不同水系特征的环太湖各水资源分区为研究单元, 结合其水文条件揭示环太湖及不同水资源分区人出 湖总磷浓度和负荷时空变化规律的研究却鲜见报道. 以水资源分区为单元分析人出湖河流水量、总磷浓度、 负荷变化规律, 有利于针对不同分区的水系特征实施人出湖水量系统调控和水环境系统治理, 从而达到降 低人湖河流总磷浓度、削减人湖总磷负荷的目的. 为此, 本文深人分析了 2012-2018 年环太湖各水资源分 区及望虞河、太浦河两大人出河道人出总磷浓度、总磷负荷量时空变化特征. 鉴于双累积曲线法广泛运用于 
资料系列一致性检验和人类活动影响分析方面, 如降雨、径流、泥沙量等水文要素的趋势演变分析等 ${ }^{[19-21]}$, 尝试性地运用双累积曲线法分析人湖水量累积量一人湖总磷负荷累积量的关系以揭示水污关系变化特征. 在结果分析的基础上, 讨论了人湖总磷负荷的影响因素以及控制途径, 可为太湖外源磷控制和太湖富营养 化治理提供科学依据.

\section{1 资料与方法}

\section{1 资料收集与处理}

2012-2018 年人出太湖水量资料依据江苏省水文水资源勘测局提供的环太湖水文巡测 (图 1) 获得. 环 太湖共 130 个测流断面,共 10 个巡测段及基准站,另有五里湖闸、梅梁湖泵站、犊山闸、望亭立交等 13 个流 量单站. 出人湖河流水量由环太湖巡测段流量计算而来, 巡测段基点站和单站每日定时流量测验, 利用各段 基点站流量与巡测段流量关系公式推算巡测段流量. 巡测断面流向规定人湖为正、出湖为负, 人出湖流量同 时记录. 论文中所采用的 2012-2018 年人出太湖主要河流的水质资料分别由江苏省水文水资源勘测局无 锡分局、常州分局、苏州分局提供. 水质监测断面基本与水量巡测段面一致, 环太湖江苏段出人湖河流设置 水质站点 84 处, 其中苏州 53 处, 无锡 27 处, 常州 4 处, 浙江段出入湖河流设置水质站点共 18 处, 其中长兴 县 9 处, 湖州市吴兴区 9 处 (图 1). 水质监测项目为氨氮、总磷、总氮、高锰酸盐指数、化学需氧量等指标, 水 质化验方法采用国家标准分析方法, 其中总磷浓度测定采用钿酸铵分光光度法 (GB/T 11893-1989). 无锡 分局水质监测频次多为每月 2 次,其他分局水质监测频次多为每月 1 次.

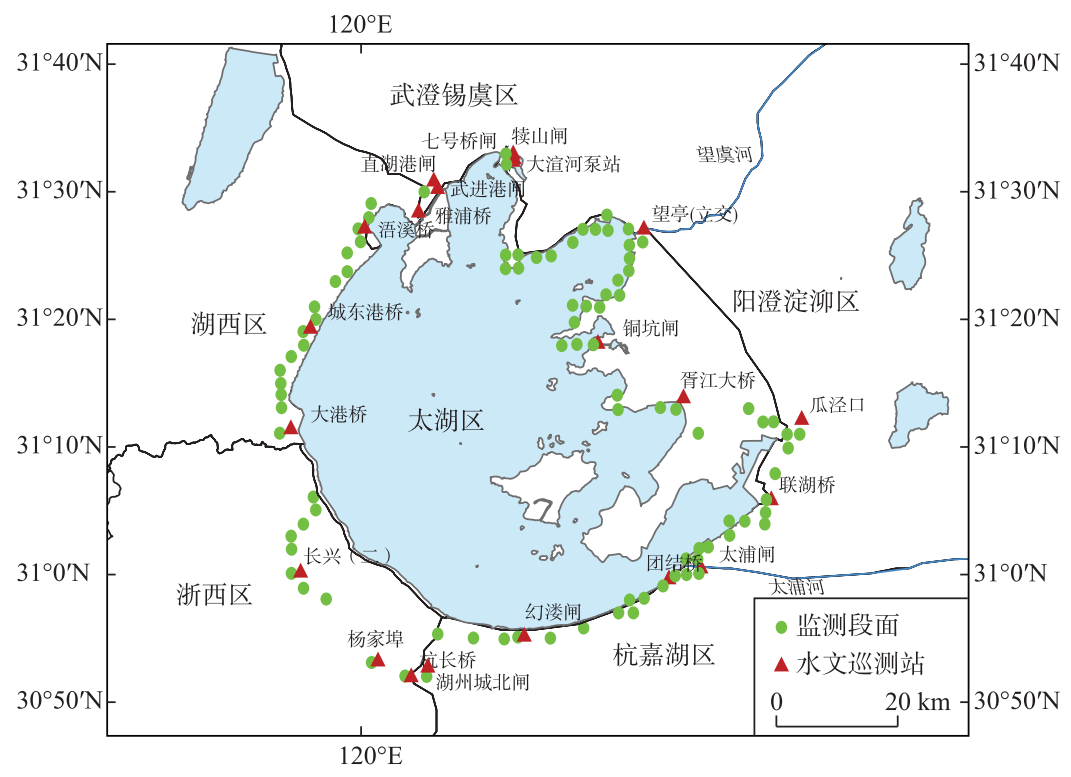

图 1 环太湖水文巡测主要站点

Fig. 1 The main stations of hydrological survey and water resources division in Taihu Basin

\section{2 研究方法}

1.2.1 出入湖总磷年负荷和年平均浓度计算 将环太湖巡测线按水资源分区进行划分 (表 1). 太浦河、望虞 河进出水量单独计算. 基于 2012-2018 年环太湖水文巡测流量数据、水质监测数据,计算 5 个水资源分区 人出湖以及望虞河、太浦河两条主要河流的人出太湖总磷负荷量. 部分受闸门控制的河道以及存在往复流 现象的河道, 可能既是人湖河道, 也是出湖河道, 在计算人出湖污染负荷时以人湖为正、出湖为负. 在计算不 同水资源分区年人出湖总磷负荷时, 先由各巡测段日人、出湖流量换算成月人出湖水量, 分别将月人、出湖 水量与巡测段内水质监测断面月平均浓度相乘 (若该月水质监测频率为每月 2 次, 则监测断面月平均浓度 为两次平均, 若为每月 1 次, 则监测数据作为断面月平均浓度), 得到巡测段内河流月人、出湖总磷负荷, 并 
累加得到其年人出湖负荷, 进而在空间上累加得到水资源分区内河流人出湖负荷. 数学公式 ${ }^{[22]}$ 为:

表 1 巡测段、站归类

Tab.1 Classification of hydrological survey sections and stations

\begin{tabular}{|c|c|c|c|}
\hline 水资源分区 & 段、站 & 水资源分区 & 段、站 \\
\hline \multirow[t]{3}{*}{ 浙西区 } & 长兴段 & 武澄锡虞区 & 沿湖小闸段 \\
\hline & 杨家埠 & & 五里湖闸 \\
\hline & 杭长桥 & & 梅梁湖泵站 \\
\hline \multirow[t]{3}{*}{ 杭嘉湖区 } & 湖州城北闸 & & 犊山闸 \\
\hline & 幻溇闸 & & 大渲河泵站 \\
\hline & 团结桥 & & 七号桥闸 \\
\hline 太浦河 & & & 直湖港闸 \\
\hline \multirow[t]{4}{*}{ 阳澄淀泖区 } & 联湖桥段 & & 武进港闸 \\
\hline & 瓜泾口段 & & 雅浦桥 \\
\hline & 胥江大桥段 & 湖西区 & 浯溪桥段 \\
\hline & 铜坑闸段 & & 城东港桥段 \\
\hline 望虞河 & & & 大港桥 \\
\hline
\end{tabular}

$$
\begin{aligned}
& W_{\text {分区人 }}=\sum_{1}^{n} \sum_{j=1}^{12}\left(C_{j} \cdot Q_{\text {入 }}\right) \\
& W_{\text {分区出 }}=\sum_{1}^{n} \sum_{j=1}^{12}\left(C_{j} \cdot Q_{\text {出 } j}\right)
\end{aligned}
$$

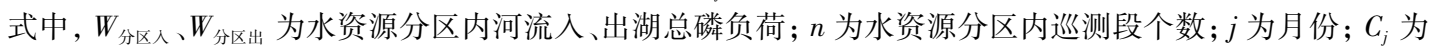
巡测段水质监测断面总磷月平均浓度; $Q_{\lambda_{j}} 、 Q_{\text {出 } j}$ 为巡测段月人、出湖水量.

不同于通常采用的算术平均法计算人出湖总磷平均浓度, 考虑到环太湖不同河道、巡测段人出湖水量、 水质在时空上呈现明显的差异性, 采用以水量为权重的加权平均法计算各水资源分区及环太湖河道人出湖 总磷年平均浓度,计算公式为:

$$
\begin{gathered}
C_{\text {分区人 }}=\frac{\sum_{1}^{n} \sum_{j=1}^{12}\left(C_{j} \cdot Q_{\text {入 }}\right)}{\sum_{1}^{n} \sum_{j=1}^{12} Q_{\text {入 }}}=\frac{W_{\text {分区人 }}}{Q_{\text {分区人 }}} \\
C_{\text {分区出 }}=\frac{\sum_{1}^{n} \sum_{j=1}^{12}\left(C_{j} \cdot Q_{\text {出 } j}\right)}{\sum_{1}^{n} \sum_{j=1}^{12} Q_{\text {出 } j}}=\frac{W_{\text {分区出 }}}{Q_{\text {分区出 }}}
\end{gathered}
$$

式中, $C_{\text {分区人、 }} C_{\text {分区出 }}$ 为加权平均法计算的各水资源分区河道人、出湖总磷年平均浓度,其余参数意义同上.

1.2.2 基于双累积曲线法的入湖水量一总磷负荷关系分析 以年水量累积值作为横轴、总磷年负荷累积量作 为纵轴, 点绘环太湖及各水资源分区河流年水量累积值一总磷年负荷累积量的双累积曲线, 分析曲线斜率突 变情况, 探明以总磷为污染物代表的水污关系 (即总磷污染形成机制) 变化规律.

1.2.3 基于月尺度的入湖水量一总磷负荷及入湖总磷浓度一负荷相关分析 首先利用 SPSS 22 软件计算各水 资源分区河流月人湖水量一月入湖总磷负荷及人湖总磷月平均浓度一月人湖总磷负荷之间的 Pearson 相关 系数, 再依据相关系数的大小分析它们之间的相关关系. Pearson 相关系数 $|r| \geqslant 0.8$ 时为高度相关, $0.4 \leqslant$ $|r|<0.8$ 为中等程度相关, $0.2 \leqslant|r|<0.4$ 为低度相关, $|r|<0.2$ 基本不相关.

\section{2 结果与分析}

\section{1 环太湖河流年入出湖总磷平均浓度变化特征}

环太湖河流人湖总磷平均浓度在 $0.189 \mathrm{mg} / \mathrm{L}$ 上下波动, $2013-2015$ 年期间逐年降低,但在 2015 年之后 
有所升高, 直到 2017 年以后又有所下降; 出湖总磷浓度呈上升趋势, 由 $0.075 \mathrm{mg} / \mathrm{L}$ 上升到 $0.083 \mathrm{mg} / \mathrm{L}$ (图 2 ). 对照《地表水环境质量标准》( GB 3838-2002) 中地表河道水质分类标准, 人湖总磷浓度一直处于 III 、 IV 类水质的临界水平, 而出湖总磷浓度一直维持在 II 类水质. 人湖河流水质明显比出湖的差, 且人湖总磷浓度 也显著高于太湖湖体总磷多年平均浓度 $(0.078 \mathrm{mg} / \mathrm{L})^{[23]}$. 出湖总磷多年平均浓度为 $0.079 \mathrm{mg} / \mathrm{L}$, 与太湖湖 体的相近. 此外, 以所有环太湖河流为整体, 其人湖水量一总磷负荷双累积曲线 (图 3) 没有明显转折点, 表明 2012－2018 年间环太湖人湖河流总磷年平均浓度随时间没有发生明显变化. 由此可见, 环太湖人湖河流总 磷污染治理效果不明显.

\section{2 环太湖河流入出湖总磷年负荷及净入湖负荷变化特征}

环太湖河流人出湖总磷年负荷、年水量变化如图 4 所示. 人出湖负荷、净人湖负荷变化过程基本一致, 最低值发生在 2013 年, 分别为 1790.8 、711.2 和 $1079.6 \mathrm{t}$, 之后增加, 2016 年达到峰值, 分别为 2993.9、1341.1 和 $1652.8 \mathrm{t}$, 之后又开始减小. 2012-2018 年间累积人湖负荷达到 $15445.59 \mathrm{t}$, 累积出湖负荷为 $6116.08 \mathrm{t}$, 累 积净人湖负荷为 $9329.51 \mathrm{t}$, 累积人湖负荷始终大于累积出湖负荷, 且累积人湖负荷增长率为 $2288.87 \mathrm{t} / \mathrm{a}$, 明 显大于累积出湖负荷增长率 $938.61 \mathrm{t} / \mathrm{a}$, 累积净人湖负荷增长率为 $1315.02 \mathrm{t} / \mathrm{a}$.

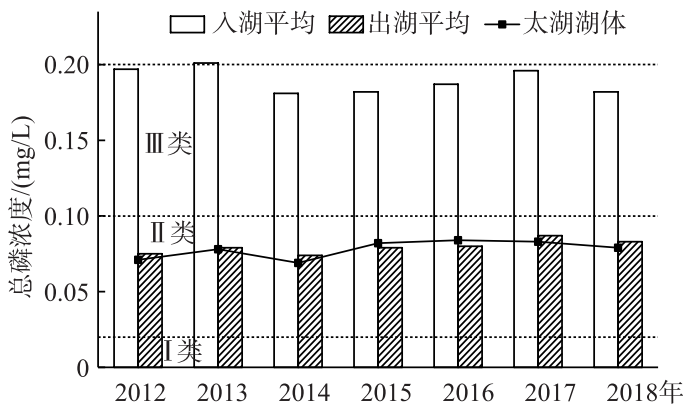

图 2 太湖湖体及环太湖河流人出湖平均总磷浓度

Fig. 2 The average total phosphorus concentration in the lake body and the rivers around Lake Taihu

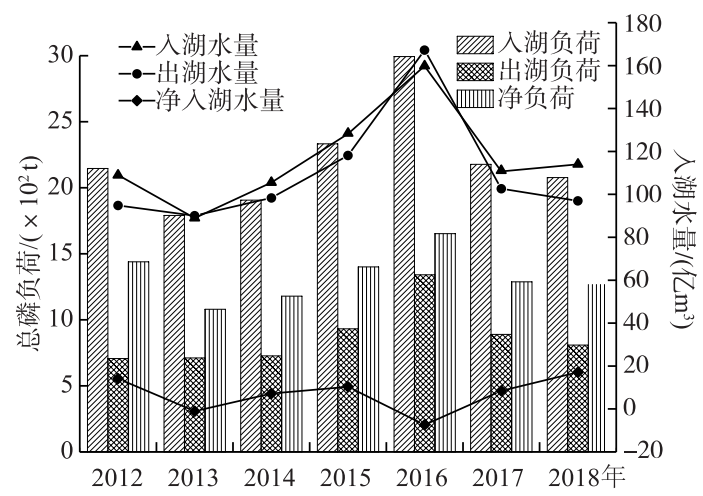

图 4 环太湖河流人出湖年总磷负荷

Fig.4 Annual total phosphorus load of rivers into and out of Lake Taihu

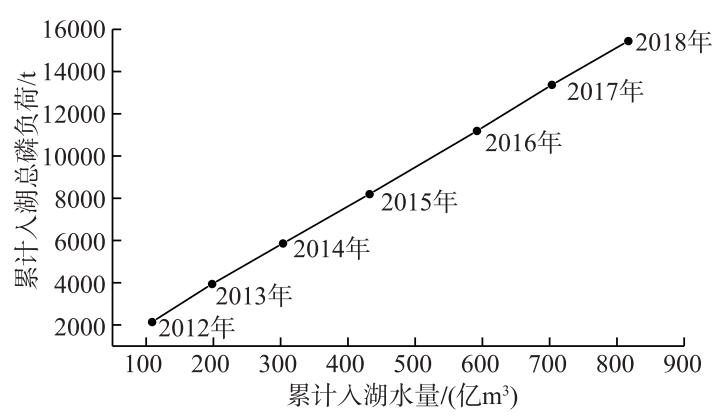

图 3 环太湖河流人湖水量一总磷负荷双累积曲线

Fig.3 Double accumulation curve of water inflow and total phosphorus load of rivers around Lake Taihu

人出湖总磷负荷在很大程度上受水量变化控 制 ${ }^{[24]} .2013$ 年枯水年( 年降水量大于多年平均值), 整个太湖流域降水较少, 人湖水量偏枯, 人出湖总 磷负荷也较少. 2016 年丰水年 (年降水量大于多年 平均值), 人湖水量达到 1999 年以来的最大值, 人 出湖总磷负荷也达到峰值. 环太湖人出湖河流净人 湖总磷负荷始终为正值, 说明在研究时段每年由人 湖水流带人太湖的总磷负荷始终高于出湖水流带 出的总磷负荷.

\section{3 各水资源分区河流入出湖总磷年平均浓度变化 特征}

由加权平均法计算得到的各水资源分区河流 人出太湖总磷浓度变化如图 5 所示, 其变化特征随 水资源分区变化而变化. 从年际变化趋势来看, 湖 西区人湖总磷浓度呈下降一上升一下降的变化规

律, 但始终处于IV 类水质, 2016 年人湖总磷浓度 $(0.230 \mathrm{mg} / \mathrm{L})$ 最高; 武澄锡虞区、杭嘉湖区人湖总磷浓度波 动较大, 但 2016 年后下降明显; 望虞河、浙西区、阳澄淀泖区自 2015 年起人湖总磷浓度均呈上升趋势. 在空 间分布上,不同水资源分区 2012- 2018 年人湖总磷多年平均浓度由高至低排序依次为湖西区 $(0.226 \mathrm{mg} / \mathrm{L})>$ 
武澄锡虞区 $(0.192 \mathrm{mg} / \mathrm{L})>$ 望虞河 $(0.135 \mathrm{mg} / \mathrm{L})>$ 浙西区 $(0.119 \mathrm{mg} / \mathrm{L})>$ 杭嘉湖区 $(0.097 \mathrm{mg} / \mathrm{L})>$ 阳澄淀泖 区 $(0.090 \mathrm{mg} / \mathrm{L})$. 综合来看太湖西北部河流人湖总磷浓度高于太湖东南部的, 江苏片区的高于浙江片区的, 与吕文等 ${ }^{[13]}$ 的分析结果一致. 除阳澄淀泖区外, 其他水资源分区人湖总磷浓度普遍大于太湖湖体的总磷浓 度. 此外, 从人湖水量一总磷负荷双累计曲线斜率的变化规律 (图 6) 可以发现, 湖西区、望虞河人湖总磷年平 均浓度没有明显变化, 浙西区的在 2015 、2014 年有所减小, 但之后均无明显变化, 而武澄锡虞区、阳澄淀泖区 的却都在 2014 年突然增大. 除杭嘉湖区外, 其他水资源分区双累积曲线斜率均没有逐年变小趋势, 表明在 这些水资源分区削减人湖河流总磷年平均浓度面临更大压力.
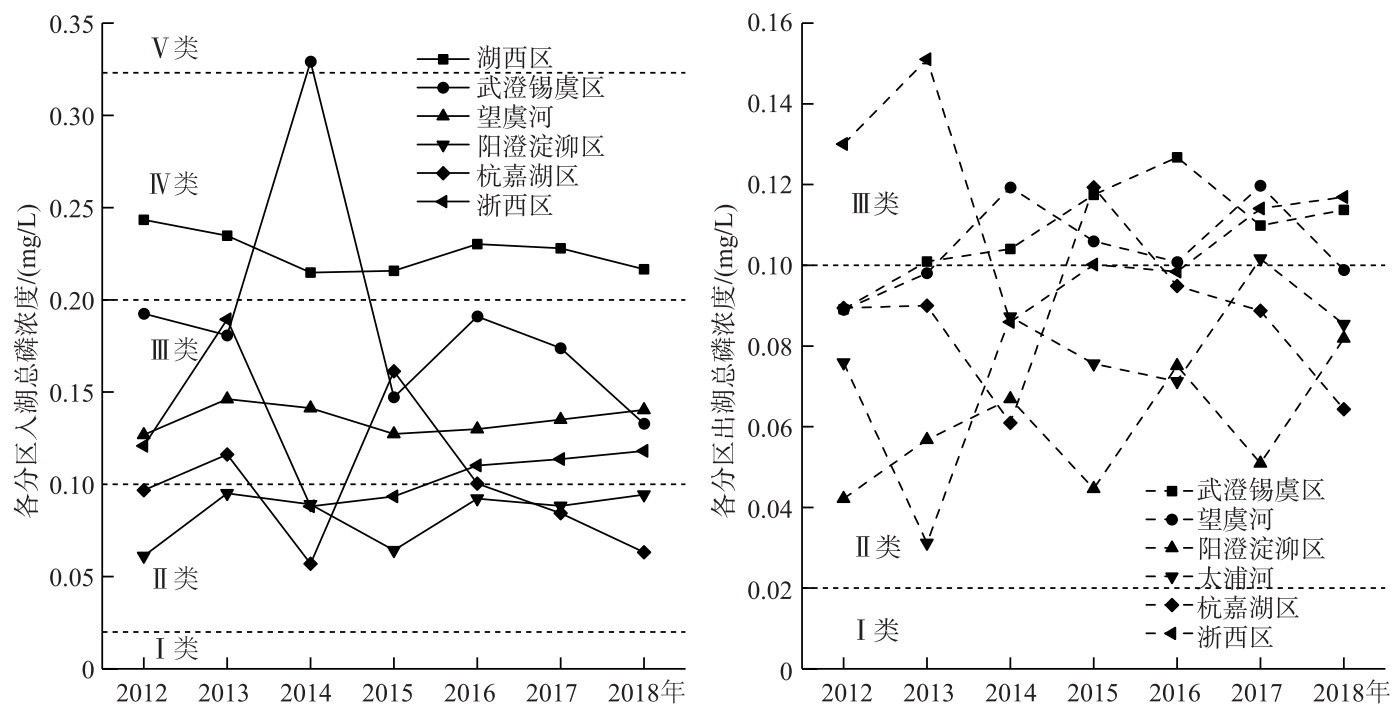

图 5 各水资源分区河流人出湖总磷浓度变化

Fig.5 Variation of total phosphorus concentration of rivers into and out of the lake in different water resources zones

出湖总磷浓度变化特征与人湖的有所不同, 年际变化上各水资源分区及望虞河、太浦河均呈明显波动 变化, 2012-2018 年出湖总磷多年平均浓度由高至低排序依次为浙西区 $(0.114 \mathrm{mg} / \mathrm{L})>$ 武澄锡虞区 $(0.109$ $\mathrm{mg} / \mathrm{L})>$ 望虞河 $(0.105 \mathrm{mg} / \mathrm{L})>$ 杭嘉湖区 $(0.087 \mathrm{mg} / \mathrm{L})>$ 太浦河 $(0.075 \mathrm{mg} / \mathrm{L})>$ 阳澄淀泖区 $(0.059 \mathrm{mg} / \mathrm{L})$. 从 出湖河道总磷浓度空间差异来看, 浙西区、武澄锡虞区对应的太湖西南部、西北部湖区水质明显比东部、东 南部湖区的差.

需要指出的是, 2014 年武澄锡虞区人湖总磷平均浓度均明显高于其他年份 (图 5). 这是因为 2014 年武 澄锡虞区 7-8 月人湖水量大, 而其他月份人湖水量为零, 再加上主要人湖河道武进港 7 月总磷浓度高达 $0.359 \mathrm{mg} / \mathrm{L}$, 显著高于其他年份总磷平均浓度, 结果导致水量加权法计算得到的总磷平均浓度大. 阳澄淀泖 区 2014 年人湖总磷浓度偏高是由于主要人湖河流汻光运河 4 月总磷浓度出现特高值. 由于该年 4 月降水较 常年同期偏多 45\%, 导致通常在非汛期关闭的位于水质监测站点上下游的闸门在该月集中开闸泄水,致使 该月人湖水量占全年的比重最高, 同时非汛期期间积累的大量污染物在闸门开启后随水流进人太湖. 因此, 吘光运河 4 月总磷浓度出现特高值有可能是在闸门开启初期采样分析的结果. 为了更准确地反映总磷浓度 在时程上的变化, 建议在水文条件变化较大的月份, 加大水质采样监测频次, 更全面地掌握水利工程运行对 河道水质的影响.

\section{4 各水资源分区河流入出湖总磷年负荷变化特征}

从图 7 可以看出,不同水资源分区河流人湖总磷年负荷变化特征也不尽相同. 人湖总磷负荷主要来自 湖西区和浙西区, 其 2012-2018 年多年平均总磷负荷分别为 1748.71 和 $278.61 \mathrm{t}$. 湖西区人湖总磷负荷呈减 少一增加一减少的变化特性, 且其占总人湖比重最大, 2013 年最小 ( $1215.54 \mathrm{t}$, 占比为 $67.88 \%$ ), 2016 年最大 ( $2331.20 \mathrm{t}$, 占比为 $77.87 \%)$. 浙西区人湖总磷负荷的变化特性与湖西区的类似, 2016 年负荷最大 ( 494.58 


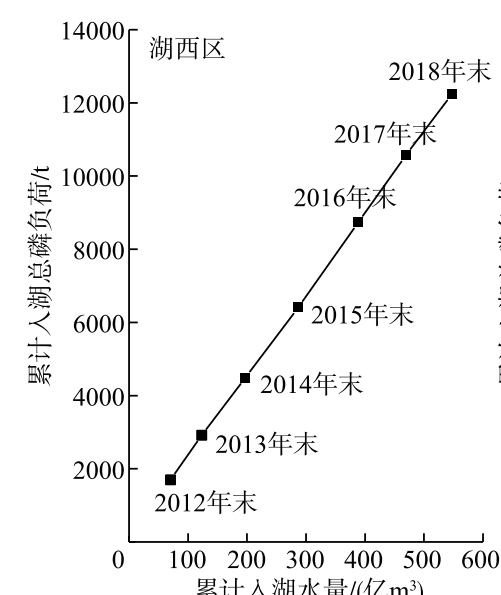

累计人湖水量 $/\left(\right.$ 亿药 $\left.{ }^{3}\right)$

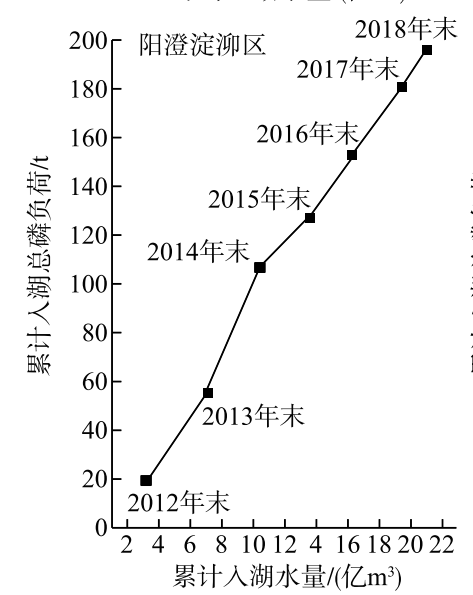

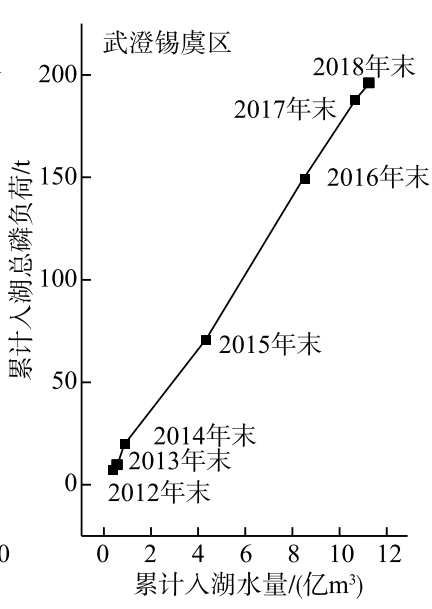

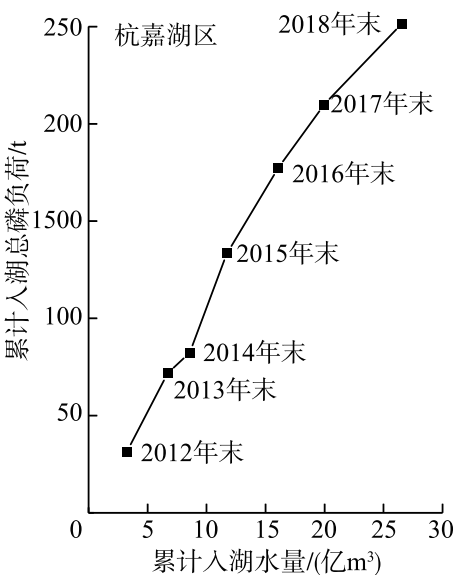

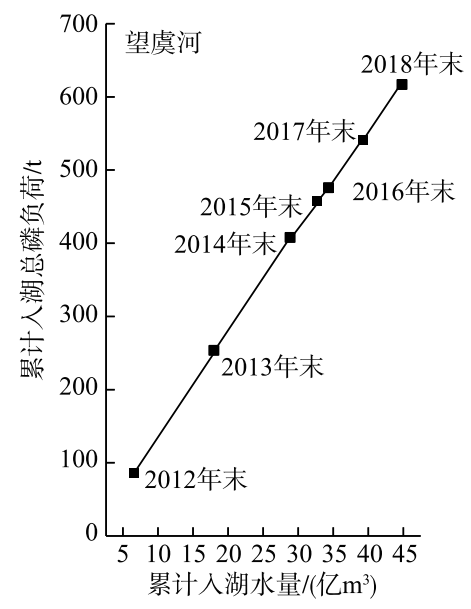

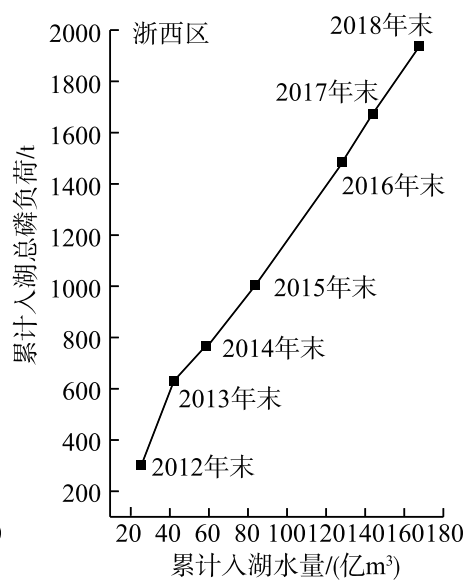

图 6 各水资源分区河流人湖水量一总磷负荷双累积曲线 (图中年份代表该年末累积值)

Fig.6 Double accumulation curve of water inflow and total phosphorus load of rivers into and out of the lake in different water resources zones

t), 但 2013 年占比最大 $(18.38 \%)$, 且其各年占比仅次于湖西区, 在 7\% 19\%之间变化. 望虞河人湖总磷负 荷多年平均值为 $87.47 \mathrm{t}$, 最大值为 2013 年的 $167.02 \mathrm{t}$; 自 2015 年开始人湖总磷负荷均少于 $100 \mathrm{t}$, 大水年 2016 年人湖总磷负荷仅为 $18.78 \mathrm{t}$; 人湖总磷负荷占比较小, 始终在 $10 \%$ 以下. 武澄锡虞区、阳澄淀泖区、杭嘉 湖区入湖总磷负荷占比太小, 在此不做详细分析.

太浦河出湖总磷负荷多年平均值为 $272.27 \mathrm{t}$, 高于其他分区, 但不同年份的出湖总磷负荷取决于流域降 雨径流大小. 2013 年枯水年, 出湖水量较少 (10.90亿 $\left.\mathrm{m}^{3}\right)$, 相应的出湖总磷负荷也较少 (33.96 t), 仅占总出 湖负荷的 4.78\%. 2016 年丰水年, 因其作为主要排水通道承接东太湖来水同时兼排杭嘉湖区涝水, 出湖水量 最多 ( 68.02 亿 $\mathrm{m}^{3}$ ), 出湖总磷负荷也最多 $484.53 \mathrm{t}$ ), 占比高达 $46.40 \%$. 阳澄淀泖区、杭嘉湖区、望虞河出湖 总磷负荷多年平均值分别为 $159.58 、 154.99$ 和 $121.05 \mathrm{t}$, 占总出湖负荷的多年平值比重分别为 $18.37 \%$ 、 $18.84 \%$ 和 $12.43 \%$, 次于太浦河. 其中望虞河 2016 年发挥排水功能导致出湖水量骤增, 出湖总磷负荷最大 (347.50 t). 武澄锡虞区和浙西区出湖总磷负荷对总出湖的贡献小,具体分析不再赘述.

\section{5 总磷浓度、负荷计算结果与相关文献的对比分析}

从图 8 可以看出, 本论文所计算的总磷人湖负荷与相关文献的相差不大, 且变化趋势基本一致. 但从总 磷平均浓度来看, 则有所差异. 鉴于不同数据源的监测点位置、采样时间和频次以及水质监测数据与巡测段 水量数据的匹配方式可能都存在差异, 因此朱伟等 ${ }^{[25]}$ 与王华等 ${ }^{[26]}$ 使用与本文不同的数据源计算得到的总 

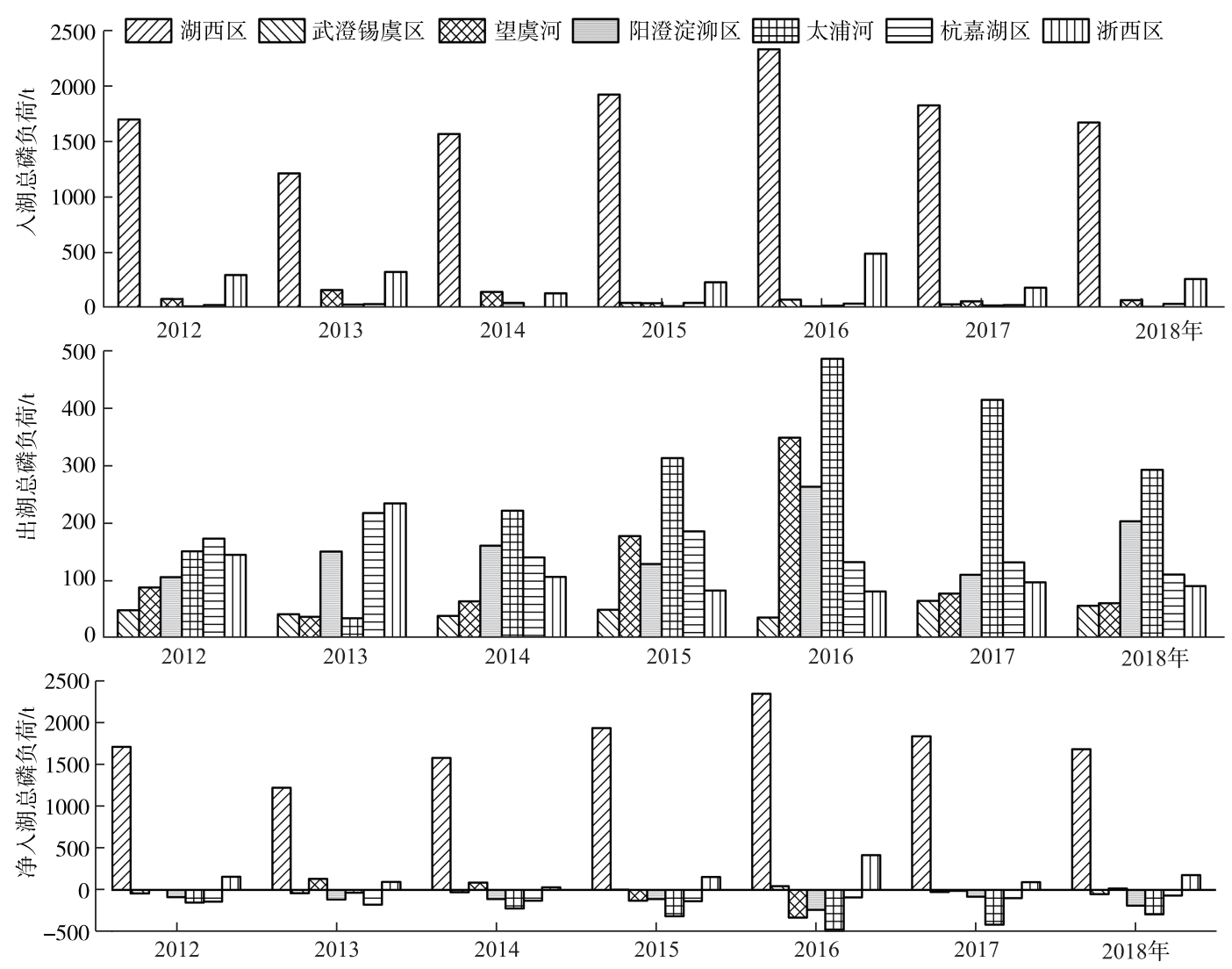

图 7 各水资源分区河流入出湖总磷负荷及净人湖总磷负荷

Fig.7 The total phosphorus load of rivers into and out of the lake in different water resources zones

磷浓度与本文有所不同. 而吕文等 ${ }^{[13]}$ 采用与本文相同的、由水利系统提供的水量水质资料,在计算巡测段 平均浓度如城东港桥段人湖总磷浓度时,如果仅考虑城东港等主要基点站的断面总磷浓度,两者的计算结 果基本一致. 但本论文认为在计算该巡测段入湖总磷浓度时,应该综合考虑社渎、官渎、交渎、洪巷港、城东 港等多个断面的总磷浓度,因此两者计算结果有所差别. 下面主要分析论证在使用相同资料情况下算术平 均法和水量加权法计算人湖总磷平均浓度的合理性.

表 2 为算术平均法和水量加权法分别计算得到的太湖西北部主要人湖河流总磷年平均浓度. 从图 9 可 以看出, 殷村港和太滆运河的总磷浓度各月相差不大, $C_{\text {河流入 }}=\sum_{j=1}^{12}\left(C_{j} \cdot Q_{\lambda_{j}}\right) / \sum_{j=1}^{12} Q_{\lambda_{j}}$ 中 $C_{j}$ 可近似作为 常数项提取出来,而水量权重变化对浓度计算结果没有影响, 因此算术平均法与水量加权法的计算结果接 近. 陈东港除 8 月份总磷浓度略高外其余月份差别不大, 水量权重对浓度计算结果几乎没有影响, 因此算术 平均法与水量加权法的计算结果差别不明显. 但对于武进港和雅浦港, 通过水量加权计算得到的总磷年平 均浓度却明显大于算术平均浓度, 其原因在于武进港、雅浦港等闸控河道冬春季水质明显优于汛期水质,但 冬春季因关闸而无人湖水量, 水量加权法没有考虑关闸期, 其计算结果主要取决于汛期较高的浓度值, 但算 术平均法把冬春季关闸期的低浓度也纳人计算. 因此, 水量加权法更能反映人湖河流水量、水质的年内差异.

人出湖河流水量、水质的空间分布差异也会使总磷的水量加权浓度和算术平均浓度不同. 由表 2 可以看 出, 城东港一殷村港一太滆运河段人湖总磷年平均浓度的算术平均值大于水量加权平均值, 这是由于 3 条河流 中城东港人湖水量占比明显偏高, 但浓度最低, 水量加权浓度主要受城东港浓度影响, 而算术平均值会因殷村 港、太滆运河总磷浓度较高而使计算结果偏大. 水量加权法能反映人湖河流水量、水质在空间上的分布不均. 

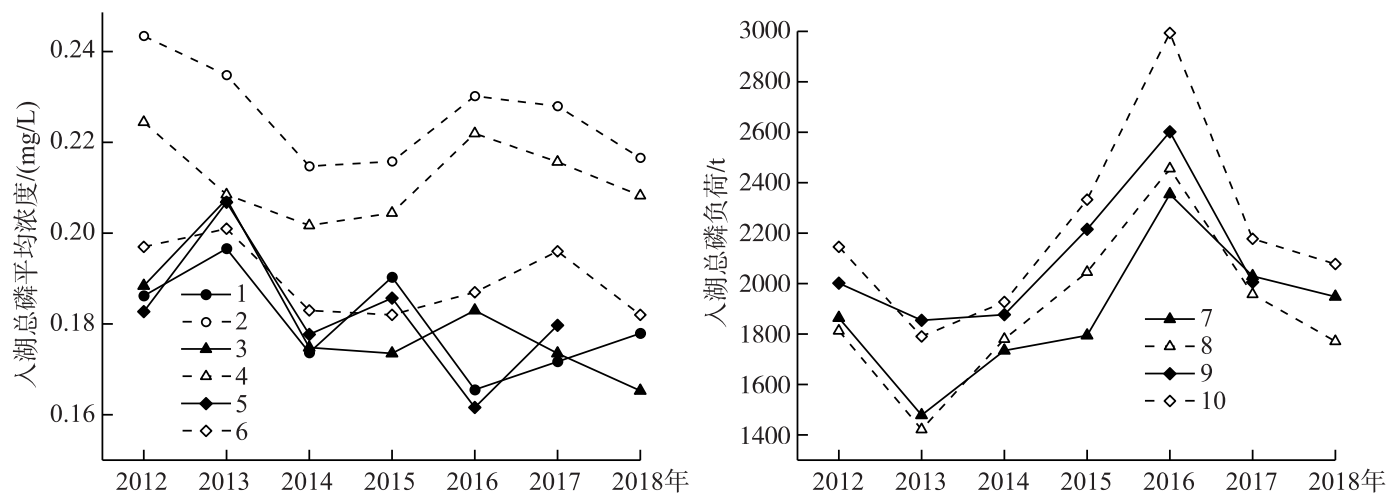

图 8 本研究与其他研究中人湖总磷平均浓度和负荷的对比

(1、2 分别为朱伟等 ${ }^{[25]}$ 与本文计算得到的湖西区河流人湖总磷平均浓度;

$3 、 4$ 分别为吕文等 ${ }^{[13]}$ 与本文计算得到的江苏段河流人湖总磷浓度; $5 、 6$ 分别为王华等 ${ }^{[26]}$ 与

本文计算得到的环太湖河流人湖总磷浓度;7、8 分别为吕文等 ${ }^{[13]}$ 与本文计算得到的江苏段人湖总磷负荷;

$9 、 10$ 分别为王华等 ${ }^{[26]}$ 与本文计算得到的环太湖入湖总磷负荷）

Fig. 8 Comparison of the average concentration and load of total phosphorus of inflows from this research and others

表 2 人湖河流总磷年平均浓度不同计算方法结果对比

Tab.2 Comparison of annual mean concentration of total phosphorus of inflows using different calculation methods

\begin{tabular}{ccccccc}
\hline \multirow{2}{*}{ 计算方法 } & \multicolumn{5}{c}{ 人湖河流总磷浓度 $/(\mathrm{mg} / \mathrm{L})$} & $\begin{array}{c}\text { 城东港一殷村港一太滆运河段 } \\
\text { 人湖总磷浓度 } /(\mathrm{mg} / \mathrm{L})\end{array}$ \\
\cline { 2 - 5 } & 城东港 & 殷村港 & 太滆运河 & 武进港 & 雅浦港 & $\begin{array}{c}\text { ( } \\
\text { 算术平均 }\end{array}$ \\
水量加权平均 & 0.199 & 0.237 & 0.266 & 0.190 & 0.169 & 0.234 \\
\hline
\end{tabular}

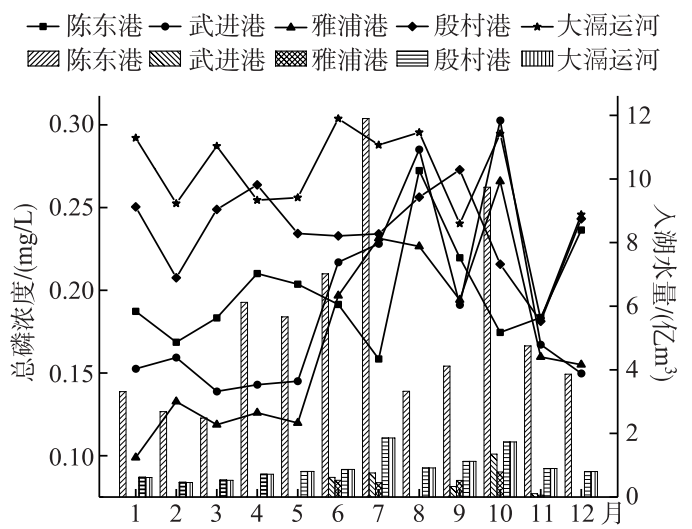

图 92016 年城东港、武进港、雅浦港总磷浓度和人湖水量的年内分配

(柱状图为人湖水量, 折线图为总磷浓度)

Fig.9 Annual distribution of total phosphorus concentration and amount of the water flowing into the lake in Chengdong Port, Wujin Port and Yapu Port in 2016

就本文数据分析结果来看, 水量加权法比算术平均法更适用于太湖流域年度人湖河流控制断面的浓度 考核及水环境治理效果的评价. 由水量加权法计算得到总磷浓度明显高于《太湖流域水环境综合治理总体 
方案 (2013 年修编) 》确定的 2020 年河道水质控制标准,江苏省尤其是太湖西北部的河道总磷负荷是太湖 总磷的主要贡献源,其水环境治理和总磷负荷控制任重而道远 ${ }^{[27-28]}$.

\section{6 入湖总磷负荷一水量一入湖河流磷浓度关系}

从表 3 可以看出, 各水资源分区月人湖总磷负荷与月人湖水量相关程度较高, 相关系数均在 0.6 以上. 而月人湖总磷负荷与月人湖总磷浓度相关程度相对较低 ${ }^{[29]}$; 除阳澄淀泖区外, 其他水资源分区月人湖水量 与月人湖总磷负荷的相关系数均大于月人湖总磷浓度与负荷的相关系数, 表明这些区月人湖水量变化对月 人湖总磷负荷变化的影响要大于月入湖总磷浓度. 从线性回归分析结果 (图 10) 也可以看出, 湖西区、武澄 锡虞区、望虞河、浙西区月人湖总磷负荷与月人湖水量的线性回归拟合度均较高. 总磷负荷占比最大的湖西 区月尺人湖总磷负荷与月人湖水量线性回归的决定系数 $R^{2}$ 高达 0.93 .

湖西区和望虞河的月入湖总磷负荷一月人湖水量点据分布非常集中, 表明湖西区、望虞河人湖总磷月平 均浓度随月份变化不明显; 武澄锡虞区、阳澄淀泖区、杭嘉湖区、浙西区的月人湖总磷负荷一月人湖水量关系 点据中绝大部分分布较集中, 但仍有些月份明显偏离回归线, 表明 4 个水资源分区人湖总磷月平均浓度均 有突然升高或降低的情况.

表 3 各分区河流月尺度人湖总磷负荷与水量、总磷浓度的 Pearson 相关系数

Tab.3 Pearson correlation coefficient of total phosphorus load with water inflow and total phosphorus concentration of rivers in different water resources zones on monthly scale

\begin{tabular}{cllllll}
\hline \multirow{2}{*}{ 指标 } & \multicolumn{5}{c}{ 人湖总磷负荷 } \\
\cline { 2 - 7 } & 湖西区 & 武澄锡虞区 & 望虞河 & 阳澄淀泖区 & 杭嘉湖区 & 浙西区 \\
\hline 水量 & $0.93^{* *}$ & $0.89^{* *}$ & $0.99^{* *}$ & $0.63^{*}$ & $0.80^{* *}$ & $0.92^{* *}$ \\
总磷浓度 & 0.14 & $0.60^{*}$ & $0.57^{*}$ & $0.79^{*}$ & $0.53^{*}$ & 0.34 \\
\hline
\end{tabular}

$* *$ 表示 Pearson 相关系数 $>0.8$, 为极强相关, $*$ 表示 Pearson 相关系数在 $0.4 \sim 0.8$ 之间, 为中等程度相关.

\section{3 讨论}

\section{1 入湖总磷负荷影响因素}

由前文分析可知, 与其他水资源分区相比, 湖西区人湖河流不仅水质相对较差, 同时受上游水系来水影 响, 水量也明显偏大且呈增加趋势 ${ }^{[30]}$, 由此可见, 其人湖水量大与人湖河流水质差的叠加作用造成其人湖总 磷负荷显著高于其他分区, 其各年占比均在 $65 \%$ 以上. 因此, 改善人湖河流水质、减少人湖水量对控制湖西 区总磷人湖负荷极其重要, 从而很有必要以湖西区为例探明人太湖水量、总磷浓度的影响因素, 为削减人湖 总磷负荷提供科学依据.

季海萍等 ${ }^{[31]}$ 分析发现全流域人湖水量一降水量 1998- 2017 年的系列与 1986-1997 年的系列存在分层， 相同降水条件下人湖水量有明显增加, 所以认为除降水外的其他因素可能正主导人湖水量变化, 而江苏段沿 江引水量与江苏人湖水量的变化趋势、节点、幅度基本一致,沿江引水量是人湖水量的重要影响因素. 从图 11 、 表 4 来看, 环太湖、湖西区人湖水量的增加趋势比全流域、湖西区、浙西区降水量的更加显著, 环太湖、湖西区和 浙西区人湖水量 2005- 2018 年的多年平均值相比 1990-2004 年分别增加了 23\%、53.11\% 和 10.10\%,而全流 域、湖西区和浙西区降水的增幅分别仅有 $5.88 \% 、 8.19 \%$ 和 $4.51 \%$, 在降水相近条件下, 人湖水量有了明显增加. 秦伯强 ${ }^{[4]}$ 指出当前太湖年来水量增量的很大一部分是由于流域整体用水量增加而进人城镇给排水循环系统 的长江引水, 陈洁等 ${ }^{[32]}$ 指出调水、补水、和冲水等水环境治理措施也会使得一部分引江水量进人太湖. 经统计, 环太湖和湖西区沿江引水量 2005-2018 年的多年平均值相比 1990-2004 年分别增加了 51.18\% 和 26.57\%,均 呈显著增加趋势. 因此科学调度与管理引水工程, 根据流域来水丰枯情况, 合理地制定引水方案, 使得引水工

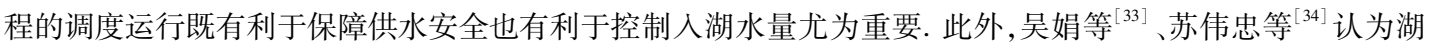
西区城镇面积扩展导致的地表不透水面积增加会使地表径流增加进而增加人湖水量.

强降雨形成的地表径流可携带大量污染物质进人湖体, 导致人湖总磷负荷增加. 以 2016 大水年为例, 2016 年湖西区年降水量达到 $2025.5 \mathrm{~mm}$, 超过常年降水量的 $73.3 \%, 2016$ 年人湖负荷也明显高于其他年份. 

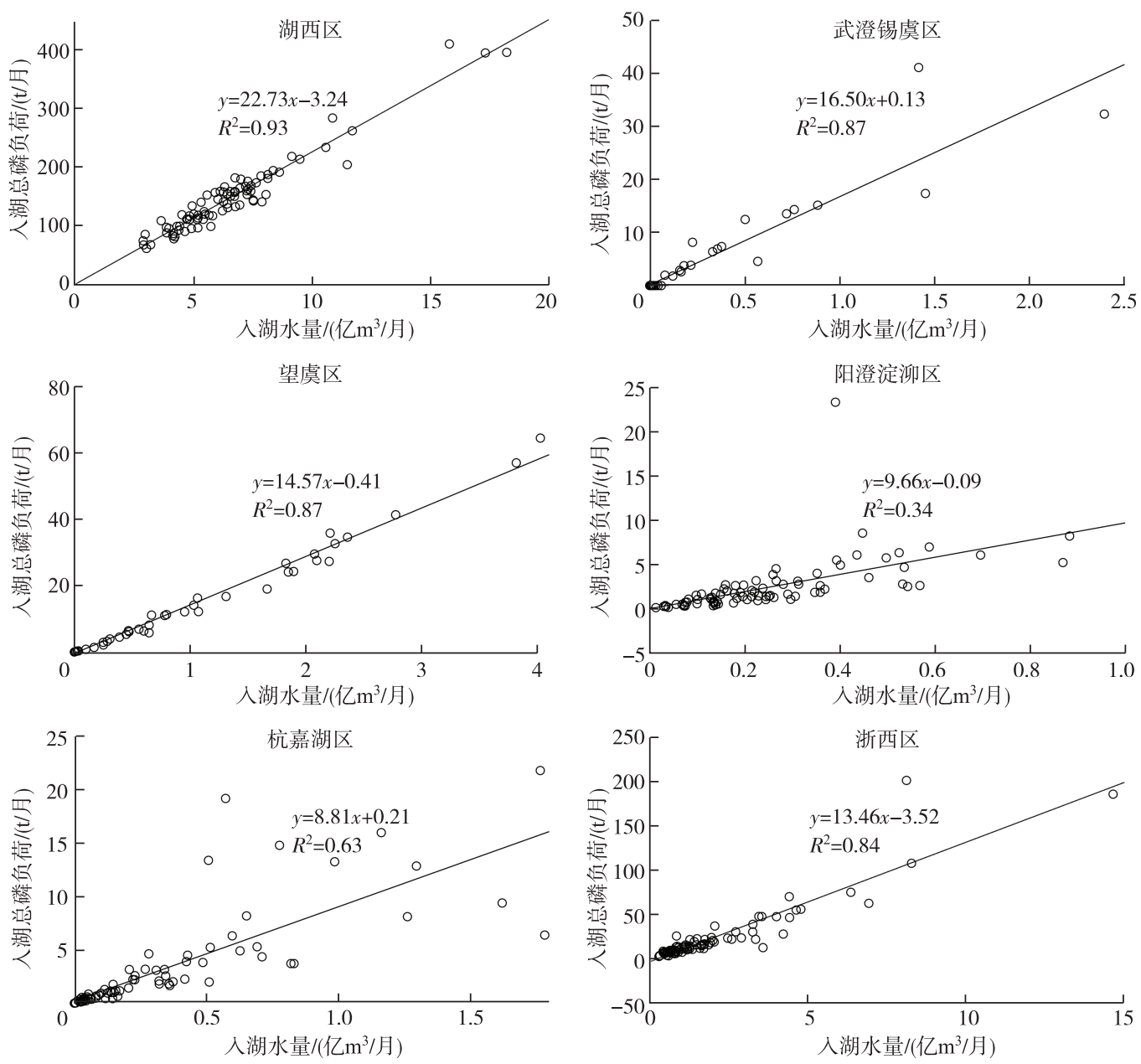

图 10 各分区河流月尺度人湖总磷负荷一水量回归分析

Fig.10 Regression analysis of total phosphorus load and amount of the water flowing into the lake from rivers in different water resources zones on monthly scale

表 4 全流域及湖西区和浙西区降水量、人湖水量和沿江引水量统计

Tab.4 Statistics of precipitation, water flowing into lake and water diversion in the whole basin,

Huxi zone and Zhexi zone

\begin{tabular}{cccc}
\hline 指标 & TFPW-MK 统计值 & $1990-2004$ 年平均值 & $2005-2018$ 年平均值 \\
\hline 全流域降水量 $/ \mathrm{mm}$ & $2.17^{*}$ & 1213.88 & 1285.24 \\
湖西区降水量 $/ \mathrm{mm}$ & $2.17^{*}$ & 1155.49 & 1250.08 \\
浙西区降水量 $/ \mathrm{mm}$ & 1.33 & 1408.39 & 1471.85 \\
环太湖人湖水量 $/\left(\right.$ 亿 m $\left.{ }^{3}\right)$ & $4.04^{* *}$ & 86.65 & 106.62 \\
湖西区人湖水量 $/\left(\right.$ 亿 m $\left.{ }^{3}\right)$ & $5.54^{* *}$ & 45.30 & 69.36 \\
浙西区人湖水量 $/\left(\right.$ 亿 $\left.{ }^{3}\right)$ & 1.08 & 19.61 & 21.59 \\
环太湖沿江引水量 $/\left(\right.$ 亿 $\left.\mathrm{m}^{3}\right)$ & $3.42^{* *}$ & 33.43 & 50.54 \\
湖西区沿江引水量 $/\left(\right.$ 亿 $\left.\mathrm{m}^{3}\right)$ & $2.46^{*}$ & 17.09 & 21.63 \\
\hline
\end{tabular}

* 代表统计值大于 1.96 , 通过了置信度为 $95 \%$ 的显著性检验; ** 代表统计值大于 2.58 , 通过了 $99 \%$ 的显著性检验; TFPWMK 统计值无单位. 
2016 年降水量 $6 、 7$ 月最大, 相应的 $6 、 7$ 月人湖水量、人湖总磷负荷也最大 ${ }^{[17]}$, 表明丰沛的降雨所产生的地表 径流携带了大量面源污染物排人河道. 再者, 河道内风浪扰动、水动力扰动作用使得河道沉积物中的磷再悬 浮, 随径流入湖, 也会增加入湖磷负荷 ${ }^{[35]}$.
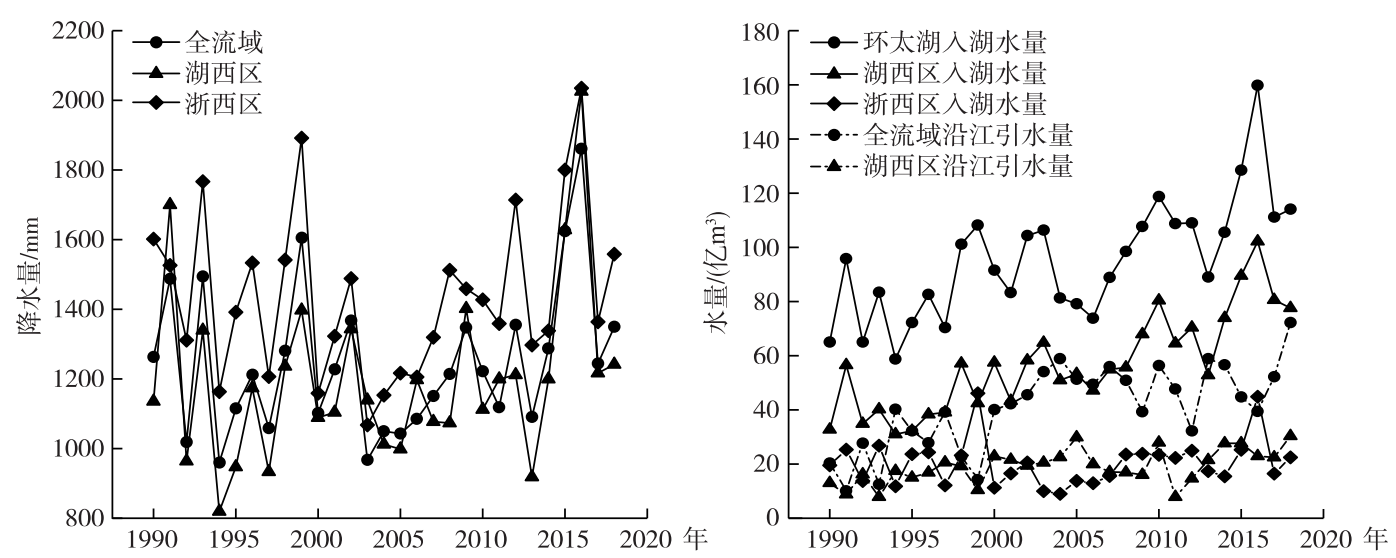

图 11 全流域及湖西区、浙西区降水量、人湖水量和引江水量变化过程

Fig.11 Variation of precipitation, water flowing into the lake and water diversion in the whole basin,

Huxi zone and Zhexi zone

\section{2 太湖外源磷污染控制}

人湖总磷负荷量大是实现太湖水体总磷治理目标的关键挑战之一,需要从流域层面上控制总磷污染物 进人水体. 以下针对不同水资源分区的总磷负荷变化特点,对控制措施进行讨论.

3.2.1 湖西区 为了控制丰水年面源污染负荷, 应重点关注降雨事件过程中人湖河流总磷浓度、负荷的响应 特征. 陈洁等 ${ }^{[32]}$ 、连心桥等 ${ }^{[35]}$ 发现河道氮、磷浓度在强降雨之后会出现短暂的升高现象, 再叠加人湖水量增 加的作用, 造成人湖负荷增加. 在今后的外源污染负荷控制管理中, 应建立与降水事件相匹配的高频次、高 精度的水量水质同步监测方案. 针对降雨径流导致的复杂多变的污染影响, 需要通过一些措施减少降雨径 流人湖. 郝璐等 ${ }^{[36]}$ 指出城市化导致的地表不透水面积增加会通过阻挡水分下渗以及减少植物蒸腾和冠层 截留而导致地表径流增加, 进而可能导致径流携带的污染物增加. 胥瑞晨等 ${ }^{[37]}$ 发现近 30 年江苏片区建筑用 地面积的突变点与人湖水量突变点一致,建筑面积对人湖水量的影响大于蒸发量、降水量、引水量等. 因此 可通过海绵城市建设改变城市产汇流条件、雨洪资源利用、环湖城市/城镇的水环境质量提升 ${ }^{[38-41]}$ 等措施, 减少人地表径流及其携带的污染. 以位于湖西区北部的镇江市海绵城市建设为例, 镇江市虹桥港 LID 设施 建设显著改善了河道水质 ${ }^{[42]}$ : 暴雨重现期为 1 年时, LID 设施对地表径流量的削减达到 $58.69 \%$, COD、氨氮、 总磷削减量分别为 $54.02 \% 、 55.86 \% 、 58.18 \%$, LID 设施在有效控制径流量的同时, 对雨水径流中污染物的截 留也有显著正效应.

从污染源头治理角度, 应探明主要人湖河道污染物的来源特点. 湖西区主要人湖河道污染严重, 区内工 业、居民住宅沿河分布,污染来源复杂, 应从流域层面探明污染河道沿程污染物来源与分布特征, 便于污染 分类分区治理. 连慧姝等 ${ }^{[43]}$ 分析了湖西区䗑河流域上下游监测点位水质在汛期、非汛期的沿程变化特征, 认为农业源不是主要污染源, 生活源、畜禽养殖源源才是流域污染的主要来源. 申萌萌等 ${ }^{[44]}$ 通过分析农业 非点源污染负荷的空间分布特征, 认为畜禽养殖污染对太滆运河水质影响最大. 因此, 应因地制宜地采取措 施控制生活源、畜禽养殖源造成的面源污染.

3.2.2 其他水资源分区 浙西区受苕溪水系来水影响, 是人湖水量及总磷负荷贡献的第二大水资源区, 同湖 西区一样也存在严重的面源污染问题. 需要降低面源污染风险, 严防畜禽养殖、水产养殖废水排放, 提高污 水处理能力. 武澄锡虞区虽然人湖总磷负荷占比极低, 但控制其总磷负荷也面临挑战. 双累积曲线表明其人 湖总磷浓度在 2014 年存在突然升高现象, 且最近几年没有明显降低. 武澄锡虞区直湖港、梁溪河等河道现 
均已施行闸控管理, 在大洪水期间因开闸泄洪, 常常会将闸上蓄积的大量污水排人湖体 ${ }^{[32]}$. 因此需要加强 这些河道的污染治理和点源污染监测预警,减少闸前污染物的聚集.

3.2.3 望虞河 2.4 节分析表明, “引江济太” 入湖总磷负荷占总人湖的比重均低于 $10 \%$, 尽管其人湖总磷浓 度高于湖体平均浓度, 但明显低于环太湖人湖河道的平均浓度, 总体而言属优质来水. 朱伟等 ${ }^{[25]}$ 、毛新伟 等 ${ }^{[45]}$ 的研究也表明, 现阶段 “引江济太”带人的磷负荷与近年太湖总磷浓度反弹的相关性不高. 因此, 通过 调引长江水可以改善太湖水动力条件, 增加太湖水环境容量 ${ }^{[16]}$. 另外, 望虞河作为太湖引排水重要通道, 在 丰水年, 可以通过发挥其排涝功能, 将湖体总磷负荷排出. 如 2015-2017 年间, 通过其排出湖体的总磷负荷 大于其输人湖体的. 但值得一提的是, 望虞河排水可能会使得贡湖西岸水体自西南向东北的流动加快, 从而 导致梅梁湖总磷浓度较高的湖水在贡湖西岸迅速蔓延 ${ }^{[46]}$, 同时将梅梁湖湖面的蓝藻携带至贡湖湾内进一步 恶化水质,不过此类不利影响根源还是在于太湖西北部的人湖污染负荷高.

望虞河引水虽然对太湖流域水环境改善起到积极作用, 但也应关注引江水量增加对人湖磷负荷、湖体 水动力条件以及水循环路径的影响, 科学调控引水, 充分发挥“引江济太”工程的积极作用.

\section{4 结论}

1) 2012-2018 年间环太湖河流年人湖总磷平均浓度 $(0.189 \mathrm{mg} / \mathrm{L})$ 明显高于与湖体总磷浓度相近的出 湖总磷平均浓度 $(0.079 \mathrm{mg} / \mathrm{L})$, 人湖河流水质状况不容乐观. 人湖总磷负荷多年平均值为 $2206.51 \mathrm{t}$, 也大于 出湖的 $873.73 \mathrm{t}$, 且表现出丰多枯少的变化规律, 环太湖河流年人湖总磷负荷始终大于出湖的.

2) 以水量加权法计算分区河流人出湖总磷平均浓度更为合理,结果表明西北、北部的湖西区、武澄锡虞 区以及望虞河人湖总磷平均浓度明显高于南、东南部的浙西区、杭嘉湖区、阳澄淀泖区的; 出湖总磷浓度与 对应湖区水质密切相关, 西南部、西北部出湖水质明显比东部、东南部的差. 湖西区人湖负荷占比最大, 年均 达 $67.88 \%$ 以上, 浙西区仅次于湖西区, 占比在 7\% 19\% 之间. 太浦河出湖的总磷负荷占比最大, 但在 2016 年丰水年望虞河也是磷负荷出湖的重要通道.

3) 总磷负荷占比最大的湖西区人湖河流总磷浓度没有得到有效削减, 人湖水量对入湖总磷负荷的影响 大, 在难以精准溯源和控源的背景下, 应加强降水过程中水量水质高频次同步监测, 并通过海绵城市建设和 科学合理引调江水, 控制人湖总磷负荷.

\section{5 参考文献}

[ 1 ] Qin BQ, Zhu GW. The nutrient forms, cycling and exchange flux in the sediment and overlying water system in lakes from the middle and lower reaches of Yangtze River. Science in China: Series D: Earth Sciences, 2006, (z1): 1-13.

[ 2 ] Yang XD, Anderson NJ, Dong XH et al. Surface sediment diatom assemblages and epilimnetic total phosphorus in large, shallow lakes of the Yangtze floodplain: Their relationships and implications for assessing long-term eutrophication. Freshwater Biology, 2008, 53(7) : 1273-1290. DOI: 10.1111/j.1365-2427.2007.01921.x.

[ 3 ] Dai QZ, Zhang K, Xu B. The trend of water quality variation and analysis of Meiliang bay and Dongtaihu bay in Taihu Lake from 2014 to 2018. China Rural Water and Hydropower, 2020, (7)：82-84. [代倩子, 张坤, 徐涁. 2014-2018 年太湖梅梁湖和东太湖水质变化特征分析. 中国农村水利水电, 2020, (7): 82-84.]

[ 4 ] Qin BQ. Shallow lake limnology and control of eutrophication in Lake Taihu. J Lake Sci, 2020, 32 (5) : 1229-1243. DOI: 10.18307/2020.0501. [秦伯强. 浅水湖泊湖沼学与太湖富营养化控制研究. 湖泊科学, 2020, 32(5) : 1229-1243.]

[ 5 ] Zhu W, Tan YQ, Wang RC et al. The trend of water quality variation and analysis in typical area of Lake Taihu, 20102017. J Lake Sci, 2018, 30(2) : 296-305. DOI: 10.18307/2018.0202. [ 朱伟, 谈永琴, 王若辰等. 太湖典型区20102017 年间水质变化趋势及异常分析. 湖泊科学, 2018, 30(2): 296-305.]

[6] Zhu GW, Zou W, Guo CX et al. Long-term variations of phosphorus concentration and capacity in Lake Taihu, 20052018: Implications for future phosphorus reduction target management. J Lake Sci, 2020, 32(1) : 21-35. DOI: 10.18307/ 2020.0103. [ 朱广伟, 邹伟, 国超旋等. 太湖水体磷浓度与赋存量长期变化(2005-2018 年) 及其对未来磷控制目 标管理的启示. 湖泊科学, $2020,32(1): 21-35$.]

[ 7 ] Zhu MY, Zhu GW, Nurminen L et al. The influence of macrophytes on sediment resuspension and the effect of associated nutrients in a shallow and large lake (Lake Taihu, China). PLoS One, 2015, 10(6) : e0127915. DOI: 10.1371/journal. 
pone.0127915.

[ 8 ] Xu DR, Zhou J, Zhang JH et al. Status of submerged plants and its influencing factors in east Lake Taihu. Water Resources and Power, 2020, 38(4) : 64-67, 94. [徐德瑞, 周杰, 张建华等. 东太湖沉水植物现状及影响因子分析. 水电能源 科学, $2020,38(4): 64-67,94$. ]

[ 9 ] Gao G, Zhu GW, Qin BQ et al. Alkaline phosphatase activity and the phosphorus mineralization rate of Lake Taihu. Science in China: Series D: Earth Sciences, 2006, 49(S1): 176-185.

[10] Zhu GW, Qin BQ, Zhang YL et al. Variation and driving factors of nutrients and chlorophyll-a concentrations in northern region of Lake Taihu, China, 2005-2017. J Lake Sci, 2018, 30(2) : 279-295. DOI: 10.18307/2018.0201. [朱广伟, 秦伯强, 张运林等. 2005-2017 年北部太湖水体叶绿素 a 和营养盐变化及影响因素. 湖泊科学, 2018, 30(2): 279-295.]

[11] Qin BQ, Yang LY, Chen FZ, et al. Mechanism and control technology of lake eutrophication and its application. Chinese Science Bulletin, 2006, 51(16) : 1857-1866. [秦伯强, 杨柳燕, 陈非洲等. 湖泊富营养化发生机制与控制技术及其 应用. 科学通报, 2006, 51(16): 1857-1866.]

[12] Xie AL, Xu F, Xiang L et al. Trend analysis for pollutant load of major rivers around Taihu Lake and its impact on water quality in Taihu Lake. Journal of Hohai University: Natural Sciences, 2017, 45(5): 391-397. [谢艾玲, 徐枫, 向龙等. 环太湖主要人湖河流污染负荷量对太湖水质的影响及趋势分析. 河海大学学报: 自然科学版, 2017, 45(5): 391-397.]

[13] Lv W, Yang H, Yang JY et al. Relationship between water quality in Lake Taihu and pollutant fluxes of the rivers surrounding Lake Taihu in Jiangsu Province. J Lake Sci, 2020, 32(5) : 1454-1462. DOI: 10.18307/2020.0517. [吕文, 杨 惠, 杨金艳等. 环太湖江苏段入湖河道污染物通量与湖区水质的响应关系. 湖泊科学, 2020, 32(5): 1454-1462.]

[14] Xu C, Wan RR, Yang GS et al. Water quality control plan with BATHTUB model for lake inflow rivers-a case study of total phosphorus in Northwest Lake Taihu, China. Water Science and Technology, 2019, 79(3) : 544-555. DOI: 10.2166/ wcc.2018.201.

[15] Yi J, Xu F, Gao Y et al. Variations of water quality of the major 22 inflow rivers since 2007 and impacts on Lake Taihu. $J$ Lake Sci , 2016, 28(6) : 1167-1174. DOI: 10.18307/2016.0602. [易娟, 徐枫, 高怡等. 2007 年以来环太湖 22 条主 要河流水质变化及其对太湖的影响. 2016, 28(6): 1167-1174.]

[16] Ma Q, Tian W, Wu ZM. Total phosphorus and total nitrogen concentrations of the water diverted from Yangtze River to Lake Taihu through Wangyu River. J Lake Sci, 2014, 26(2) : 207-212. DOI: 10.18307/2014.0206. [马倩, 田威, 吴朝 明. 望虞河引长江水人太湖水体的总磷、总氮分析. 湖泊科学, 2014, 26(2) : 207-212.]

[17] Zhai SH, Zhou Y, Cheng YH et al. Calculation of total phosphorus loads from rivers around Lake Taihu and analysis of total phosphorus fluctuation in the lake in 2015-2016. J Lake Sci, 2020, 32(1) : 48-57. DOI: 10.18307/2020.0105. [翟 淑华, 周娅, 程媛华等. 2015-2016 年环太湖河道进出湖总磷负荷量计算及太湖总磷波动分析. 湖泊科学, 2020, 32( 1$)$ : 48-57.]

[18] Zhu W, Hu SY, Feng GY et al. Effects of great floods on phosphorus in shallow lakes: A case study of Lake Taihu in 2016. J Lake Sci, 2020, 32(2) : 325-336. DOI: 10.18307/2020.0201. [朱伟, 胡思远, 冯甘雨等. 特大洪水对浅水 湖泊磷的影响: 以 2016 年太湖为例. 湖泊科学, 2020, 32(2) : 325-336.]

[19] Li QF, Yu MX, Lu GB et al. Impacts of the Gezhouba and Three Gorges reservoirs on the sediment regime in the Yangtze River, China. Journal of Hydrology, 2011, 403(3/4) : 224-233. DOI: 10.1016/j.jhydrol.2011.03.043.

[20] Mu XM, Basang CL, Zhang L et al. Impact of soil conservation measures on runoff and sediment in Hekou-Longmen region of the Yellow River. Journal of Sediment Research, 2007, (2) : 36-41. [穆兴民, 巴桑赤烈, Zhang Lu 等. 黄河河口镇 至龙门区间来水来沙变化及其对水利水保措施的响应. 泥沙研究, 2007, (2) : 36-41.]

[21] Ortiz RF. Methods to identify changes in background water-quality conditions using dissolved-solids concentrations and loads as indicators, Arkansas River and Fountain Creek, in the vicinity of Pueblo, Colorado. Entific Investigations Report, 2004.

[22] Zhai SH. Analysis on the change of pollution load in and out of lakes of rivers around Taihu Lake since 2000. In: Chinese Society of Water Conservancy ed. Collection of exchange on Taihu High-level Forum. Shanghai, 2004: 6. [ 翟淑华. 2000 年以来环太湖河流出入湖污染负荷量变化分析. 见: 中国水利学会. 太湖高级论坛交流文集. 上海, 2004: 6.]

[23] Taihu Basin Administration, Ministry of Water Resources ed. Tai Lake Health Report 2018. Shanghai: Taihu Basin Admin- 
istration, Ministry of Water Resources, 2018. [ 水利部太湖流域管理局. 2018 年太湖健康状况报告. 上海: 水利部太 湖流域管理局, 2018.]

[24] Ji HP, Wu HY, Wu J. Variation of inflow and outflow of Lake Taihu in 1986-2017. J Lake Sci, 2019, 31(6) : 15251533. DOI: 10.18307/2019.0612. [季海萍, 吴浩云, 吴娟. 1986-2017 年太湖出、人湖水量变化分析. 湖泊科学, 2019, 31(6) : 1525-1533.]

[25] Zhu W, Xue ZP, Zhang YM et al. Effect of water diversion from the Yangtze River to Lake Taihu on total phosphorus rebound after 2016. J Lake Sci, 2020, 32(5) : 1432-1445. DOI: 10.18307/2020.0518. [ 朱伟, 薛宗璞, 章元明等. “引 江济太”对 2016 年后太湖总磷反弹的直接影响分析. 湖泊科学, 2020, 32(5) : 1432-1445.]

[26] Wang H, Chen HX, Xu ZA et al. Variation trend of total phosphorus and its controlling factors in Lake Taihu, $2010-2017$. J Lake Sci, 2019, 31(4) : 919-929. DOI: 10.18307/2019.0421. [王华, 陈华釒, 徐兆安等. 2010-2017 年太湖总磷 浓度变化趋势分析及成因探讨. 湖泊科学, 2019, 31(4): 919-929.]

[27] Zhu X, Li GB, Wang SR. Treatment of blue algae outbreak in Taihu Lake. Water Resources Protection, 2020, 36(6) : 106-111. [ 朱喜, 李贵宝, 王圣瑞. 太湖蓝藻暴发的治理. 水资源保护, 2020, 36(6) : 106-111.]

[28] Zhang CL, Zheng SH, Liu Y et al. Suggestions on promoting the modernization of the ecological environment governance system in the Taihu Lake Basin. Environmental Protection, 2020, 48(Z2): 84-86. [张丛林, 郑诗豪, 刘宇等. 关于推 进太湖流域生态环境治理体系现代化的建议. 环境保护, 2020, 48(Z2) : 84-86.]

[29] Zhu XY, Jiang CP, Ma XY et al. Water quantity, quality and pollutant flux of inbound and outbound water in Zhejiang area of Taihu Basin. J Lake Sci, 2020, 32(3) : 629-640. DOI: 10.18307/2020.0304. [ 朱昕阳, 蒋彩萍, 马晓雁等. 太湖 流域浙江片区出人境水量、水质及污染物通量. 湖泊科学, 2020, 32(3) : 629-640.]

[30] Lin P, Chen QH, Li QF et al. Analysis on inflow and outflow of water resources zones around Taihu Lake and its contribution. Water Resources Protection, 2021, 37(3) : 66-73. [林鹏, 陈启慧, 李琼芳等. 环太湖各水资源分区人出湖水量 及贡献分析. 水资源保护, $2021,37(3): 66-73$.]

[31] Ji HP, Wu HY, Wu J. Variation of inflow and outflow of Lake Taihu in 1986-2017. J Lake Sci, 2019, 31(6) : 15251533. DOI: 10.18307/2019.0612. [季海萍, 吴浩云, 吴娟. 1986-2017 年太湖出、人湖水量变化分析. 湖泊科学, $2019, \mathbf{3 1}(6)$ : 1525-1533.]

[32] Chen J, Zhu GW, Xu H et al. Influence of rainfall intensity on the nutrient loading from an inflowing river in the plain river network of the Taihu catchment. Environmental Science, 2019, $40(11)$ : 4924-4931. DOI: 10. 13227/j. hjkx. 201905103. [陈洁, 朱广伟, 许海等. 不同雨强对太湖河网区河道人湖营养盐负荷影响. 环境科学, 2019, 40 (11) : 4924-4931.]

[33] Wu J, Hu Y, Wu J et al. Variation of water quantity into western area of Taihu Lake and influence factors. Journal of Chi$n a$ Hydrology , 2016, 36(3): 44-49. [吴娟, 胡艳, 武剑等. 太湖流域湖西区人湖水量变化及原因初步分析. 水文, 2016, 36(3): 44-49.]

[34] Su WZ, Yang GS, Chen S. An empirical analysis of urbanization spatial process and its ecological effect in western Taihu Lake Watershed of China. Acta Ecologica Sinica, 2008, 28(9): 4306-4312. [苏伟忠, 杨桂山, 陈爽. 太湖流域湖西区 城市化空间过程及其生态效应. 生态学报, 2008, 28(9): 4306-4312.]

[35] Lian XQ, Zhu GW, Yang WB et al. Effect of heavy rainfall on nitrogen and phosphorus concentrations in rivers at river-net plain. Environmental Science, 2020, 41(11): 4970-4980. DOI: 10.13227/j.hjkx.202003183. [连心桥, 朱广伟, 杨文 斌等. 强降雨对平原河网区人湖河道氮、磷影响. 环境科学, 2020, 41(11) : 4970-4980.]

[36] Hao L, Sun G. Impacts of urbanization on watershed ecohydrological processes: Progresses and perspectives. Acta Ecologica Sinica, 2021, 41(1): 13-26. [郝璐, 孙阁. 城市化对流域生态水文过程的影响研究综述. 生态学报, 2021, 41 (1): 13-26. ]

[37] Xu RC, Pang Y, Hu ZB. Analysis on the water quantity changes from Jiangsu section entering Lake Taihu from 1990 to 2019. J Lake Sci, 2021, 33(3) : 797-805. DOI: 10.18307/2021.0315. [ 胥瑞晨, 逢勇, 胡祉冰. 1990-2019 年江苏 片区人太湖水量变化及原因分析. 湖泊科学, 2021, 33(3): 797-805.]

[38] Hunt WF, Jarrett AR, Smith JT et al. Evaluating bioretention hydrology and nutrient removal at three field sites in north Carolina. Journal of Irrigation and Drainage Engineering, 2006, 132 (6) : 600-608. DOI: 10.1061/( asce) 0733-9437 (2006) 132: 6(600).

[39] Borst M, Struck SD, Muthukrishnan S et al. Swale performance for stormwater runoff low impact development. Wilmington: 
American Society of Civil Engineers, 2008. DOI: 10.1061/41007(331) 16.

[40] Mentens J, Raes D, Hermy M. Green roofs as a tool for solving the rainwater runoff problem in the urbanized 21st century?. Landscape and Urban Planning, 2006, 77(3) : 217-226. DOI: 10.1016/j.landurbplan.2005.02.010.

[41] Rushton BT. Low-impact parking lot design reduces runoff and pollutant loads. Journal of Water Resources Planning and Management, 2001, 127(3): 172-179. DOI: 10.1061/(asce)0733-9496(2001) 127: 3(172).

[42] Zhang QR, Yang DJ, Lu ZY et al. Study on non-point source pollution control of sponge city construction and its impact on river water quality. In: Editorial Board of Environmental Engineering, Industrial Construction Magazine Co., LTD eds. Proceedings of the 2019 national academic conference of environmental engineering. Beijing, 2019: 242-247. [张泉荣, 杨道军, 陆朝阳等. 海绵城市建设对面源污染控制及河道水质影响研究. 见: 《环境工程》编委会、工业建筑杂志社 有限公司.《环境工程》2019 年全国学术年会论文集. 北京, 2019: 242-247.]

[43] Lian HS, Liu HB, Li XD et al. Analysis of spatial variability of water quality and pollution sources in Lihe River Watershed, Taihu Lake Basin. Environmental Science, 2017, 38(9) : 3657-3665. DOI: 10.13227/j.hjkx.201703121. [连慧 姝, 刘宏斌, 李旭东等. 太湖䶚河小流域水质的空间变化特征及污染物源解析. 环境科学, 2017, 38(9): 3657-3665.]

[44] Shen $\mathrm{Mm}, \mathrm{Su} \mathrm{Bl}$, Li H et al. Spatiotemporal distribution of non-point source pollution in the plain river network area of the taige canal watershed. Journal of Beijing Normal University: Natural Science, 2012, 48(5) : 463-470. [ 申萌萌, 苏保林, 李卉等. 太滆运河流域平原河网地区非点源污染负荷时空分布规律研究. 北京师范大学学报: 自然科学版, 2012, 48(5) : 463-470.]

[45] Mao XW, Xu F. Comparative analysis of the impact of the main rivers around Taihu Lake and the diversion river on the water quality of Taihu Lake. Water Resources Development Research, 2018, 18(1): 29-32. [毛新伟, 徐枫. 引江济太与环 太湖主要河流对太湖水质影响的对比分析. 水利发展研究, 2018, 18(1): 29-32.]

[46] Yang X. Influence of diversion project of Wangyu river on water quality of gonghu bay and TP of main water intakes. Water Purification Technology, 2020, 39(5) : 80-85. [杨显. 望虞河引水工程对贡湖湾水质及主要取水口总磷的影响. 净 水技术, $2020, \mathbf{3 9}(5): 80-85$. $]$ 